\title{
Hubungan Kemampuan Berpikir Kritis Terhadap Motivasi Belajar Mahasiswa Melalui Penerapan Model Problem Based Learning (PBL) Dipadukan Kontekstual
}

\author{
Nurfathurrahmah"1, Fahruddin ${ }^{2}$, Bakhtiar ${ }^{3}$, Irma Rubianti ${ }^{4}$ \\ ${ }^{1234}$ Dosen Program Studi Pendidikan Biologi, STKIP Bima. Jalan Piere Tendean Kel. Mande Tel. Fax \\ (0374) 42801, Bima 84191, Indonesia \\ Email: bangfenmbozo@gmail.com
}

\begin{abstract}
Abstrak: Tujuannya untuk mengetahui adanya hubungan kemampuan berpikir kritis terhadap motivasi belajar mahasiswa melalui penerapan model Problem Based Learning (PBL) dipadukan Kontekstual. Jenis penelitian adalah ex-post facto. Variabel penelitian berupa kemampuan berpikir kritis variabel bebas (X), variable terikat (Y) motivasi belajar. Berdaasarkan perhitungan, maka dapat disimpulkan bahwa $r$ hitung $\leq r$ tabel. Berarti Ho ditolak dan Ha diterima, menunjukkan tidak ada hubungan yang signifikan kemampuan berpikir kritis terhadap motivasi belajar mahasiswa melalui penerapan model Problem Based Learning (PBL) dipadukan Kontekstual.
\end{abstract}

\section{Kata Kunci: Berpikir Kritis, Motivasi Belajar, Model Problem Based Learning, Kontekstual.}

\section{PENDAHULUAN}

Pendidikan pada hakikatnya berlangsung seumur hidup (Long life education), oleh karena demikian pendidikan harus dapat mengembangkan potensi dasar peserta didik agar berani menghadapi problema yang dihadapi tanpa rasa tertekan, mau, mampu dan senang meningkatkan fitrahnya sebagai khalifah di muka bumi (Tim Broad based Education, Depdiknas, 2007). Pendidikan diharapkan dapat membekali peserta didik dengan kecakapan hidup, yaitu keberanian menghadapi problema hidup dan kehidupan secara wajar tanpa merasa tertekan, kemudian secara kreatif menemukan solusi serta mampu mengatasinya. Harapan tersebut dapat terealisasi melalui peningkatan mutu dalam pembelajaran, menerapkan metode yang memudahkan mahasiswa untuk terlibat banyak dalam proses belajar serta memberikan pengalaman belajar yang diorientasikan pada pengalaman hidup nyata.

Kondisi yang dihadapi dalam pembelajaran mahasiswa kurang maksimal diarahkan baik melalui proses, kegiatan serta kesempatan untuk dibekali potensi guna memecahkan dan mengatasi masalah kehidupan. Kekurangan lain dari segi motivasi belajar yang masih kurang dikarena sebagian mahasiswa masih mengandalkan kemampuan 
orang lain untuk membantunya dalam belajar hal ini berpengaruh terhadap kurangnya mahasiswa mengasah serta mengembangkan keilmuannya. Kekurangan tersebut diperlukan suatu upaya salah satunya menerapkan pembelajaran model problem based learning dipadukan kontekstual dengan harapan berpengaruh positif terhadap kemampuan berpikir kritis dan motivasi belajar mahasiswa.

Pembelajaran berbasis masalah membantu untuk menunjukkan dan memperjelas cara berpikir serta kekayaan dari struktur dan proses kognitif yang terlibat di dalamnya (Rusman, 2010). Pembelajaran kontekstual merupakan proses pempelajaran yang holistik dan bertujuan membantu peserta didik untuk memahami materi ajar sehingga siswa memiliki pengetahuan, keterampilan untuk secara aktif mengkonstruksikan sendiri pemahamannya (Yamin, 2013). Tujuan penelitian inipun sesuai pernyataan "kemampuan berpikir kritis sangat diperlukan dalam pemecahan masalah atau pencarian solusi, serta pembelajaran kontekstual bertujuan memotivasi mahasiswa untuk memahami makna materi pelajaran yang dipelajarinya dengan mengkaitkan materi tersebut dengan konteks kehidupan mereka sehari-hari (konteks pribadi, sosial dan kultur)" (Nurfathurrahmah, 2018).

Berdasarakan uraian tersebut, maka rumusan masalah penelitian apakah ada hubungan kemampuan berpikir kritis terhadap motivasi belajar mahasiswa melalui penerapan model Problem Based Learning (PBL) dipadukan Kontekstual?. Tujuannya untuk mengetahui adanya hubungan kemampuan berpikir kritis terhadap motivasi belajar mahasiswa melalui penerapan model Problem Based Learning (PBL) dipadukan Kontekstual. Hipotesi penelitian terdiri dari Ha: ada hubungan yang signifikan kemampuan berpikir kritis terhadap motivasi belajar mahasiswa melalui penerapan Problem Based Learning (PBL) dipadukan Kontekstual. Ho: tidak ada hubungan yang signifikan kemampuan berpikir kritis terhadap motivasi belajar mahasiswa melalui penerapan model Problem Based Learning (PBL) dipadukan Kontekstual

\section{METODE}

Jenis penelitian adalah ex-post facto. Variabel penelitian berupa kemampuan berpikir kritis variabel bebas $(\mathrm{X})$, variable terikat (Y) motivasi belajar. Penelitian dilaksanakan pada semester II Pendidikan Biologi. Subjek penelitian 23 mahasiswa. Instrumen berupa soal essay untuk menentukan kemampuan berpikir kritis dan angket menentukan motivasi belajar. Teknik analisis data menggunakan rumus korelasi product moment (r) atau r-hitung. 


\section{HASIL DAN PEMBAHASAN}

Adapu hasil statistik dan korelasi dapat diringkas sebagai berikut:

Tabel 1. Ringkasan Hasil Statistik dan Korelasi

\begin{tabular}{cc}
\hline $\mathbf{N}$ & $\mathbf{2 3}$ \\
\hline$\sum \mathbf{X}$ & 1737 \\
$\sum \mathbf{X}^{2}$ & 137195 \\
$\sum \mathbf{Y}$ & 1896 \\
$\sum \mathbf{Y}^{2}$ & 158270 \\
$\sum \mathbf{X} . \mathbf{Y}$ & 142561 \\
rX.y (r hitung) & $-914,559$ \\
r tabel & 0,413 \\
\hline
\end{tabular}

Berdaasarkan perhitungan, maka dapat disimpulkan bahwa $\mathrm{r}$ hitung $\leq \mathrm{r}$ tabel. Berarti Ho ditolak dan Ha diterima, menunjukkan tidak ada hubungan yang signifikan kemampuan berpikir kritis terhadap motivasi belajar mahasiswa melalui penerapan model Problem Based Learning (PBL) dipadukan Kontekstual.

Kesimpulan dari hasil perhitungan menunjukkan bahwa dalam penelitian ini tidak ada hubungan maupun pengaruh kemampuan berpikir kritis terhadap motivasi belajar mahasiswa melalui penerapan model Problem Based Learning (PBL) dipadukan Kontekstual. Dimana kemampuan berpikir kritis seseorang tidak mesti di sertai dengan motivasi yang tinggi pula, bisa saja sekalipun dengan adanya motivasi belajar akan tetapi ketika adanya soal berkonteks problem based learning berusaha diselesaikan namun menemui kendala, misalnya kurang tersedianya media belajar, kesiapan siswa dalam belajar, pendidik kurang maksimal dalam membimbing mahasiswa sehingga mempengaruhi rendahnya kualitas dalam mengembangkan kemampuan berpikir kritis. Hal ini sesuai dengan hasil perhitungan besarnya sumbangan (konstribusi) variable $\mathrm{X}$ (kemampuan berpikir kritis) 83\% memberikan konstribusi terhadap variabel Y (motivasi belajar), $17 \%$ ditentukan oleh variabel lain. Hal ini senada dengan penelitian Nurfathurrahmah (2018), melalui perhitungan $\mathrm{N}-$ Gain (persentasi peningkatan) dari siklus I ke siklus II hanya $1 \%$. Ini menandakan bahwa kemampuan berpikir kritisnya peserta didik diperlukan usaha lebih banyak lagi baik dari segi kesiapan peserta didik dalam hal perluas pengetahuan, keteguhan dalam mencari informasi dari berbagai sumber belajar maupun dari segi pendidik untuk menfasilitasi serta memberikan keleluasan peserta didik dalam mengasah dan mengeksplor kemampuannya. Menurut Triyani (2012) diperlukan kontribusi positif konsep diri (kegigihan, percaya diri, serta komunikatif) dalam menunjang motivasi berprestasi secara bersama-sama terhadap hasil belajar Biologi.

Sekalipun penerapan model Problem Based Learning (PBL) dipadukan Kontekstual dapat menguntungkan bagi peserta didik, misalnya PBL dapat meningkatkan aktivitas 
pembelajaran; mengembangkan kemampuan berpikir kritis (Nuraini, 2017), pembelajaran kontekstual merupakan konsep belajar yang membantu guru mengkaitkan antara materi yang diajarkannya dengan situasi dunia nyata siswa dan mendorong siswa membuat hubungan antara pengetahuan yang dimilikinya dengan penerapan dalam hidup sehari-hari (Afriani, 2018). Begitu pula dengan penelitian Irwansyah, dan Nurfathurrahmah (2018), bahwa perangkat pembelajaran IPA terpadu berorintasi model problem based learning (PBL) dengan pendekatan integratif dapat meningkatkan kompetensi sikap dan pengetahuan siswa MTsN 2 Dompu.

Penerapan PBL selain itu juga turut mempengaruhi dilihat dari kelemahan PBL yaitu: apabila siswa mengalami kegagalan atau kurang percaya diri dengan minat yang rendah maka siswa enggan untuk mencoba lagi; membutuhkan waktu yang cukup untuk persiapan; pemahaman yang kurang tentang mengapa masalah-masalah yang dipecahkan maka siswa kurang termotivasi untuk belajar (Sanjaya, 2008) dalam (Wulandari, 2013).

\section{KESIMPULAN}

Berdasarkan hasil dan pembahasan dapat disimpulkan bahwa $\mathrm{r}$ hitung $\leq \mathrm{r}$ tabel. Berarti Ho ditolak dan Ha diterima, menunjukkan tidak ada hubungan yang signifikan kemampuan berpikir kritis terhadap motivasi belajar mahasiswa melalui penerapan Problem Based Learning (PBL) dipadukan Kontekstual.

\section{DAFTAR PUSTAKA}

Afriani A. (2018). Pembelajaran Kontekstual (Contextual Teaching and Learning) dan Pemahaman Konsep Siswa. Jurnal AlMuta'aliyah Vol 3 No 1, 2018.

Irwansyah M, Nurfathurrahmah. (2018). Pengembangan Perangkat Pembelajaran IPA Terpadu Berorintasi Model Problem Based Learning (PBL) Dengan Pendekatan Integratif Untuk Meningkatkan Kompetensi Sikap Dan Pengetahuan Siswa. Oryza Jurnal Pendidikan Biologi, Vol 7 Nomor 1 April 2018.

Nuraini F. (2017). Penggunaan Model Problem Based Learning (PBL) Untuk Meningkatkan Hasil Belajar IPA Siswa Kelas 5 SD. e-jurnalmitrapendidikan, Vol 1 Nomor 4 juni 2017.

Nurfathurrahmah. (2018). Penerapan Model Problem Based Learning (PBL) Berbasis Kontekstual Terhadap Peningkatan Kemampuan Berpikir Kritis Mahasiswa. Oryza Jurnal Pendidikan Biologi, Vol 7 Nomor 1 April 2018.

Rusman. (2010). Model-Model Pembelajaran Mengembangkan Profesionalisme Guru. Rajawali Press: Jakarta.

Tim Broad based Education, Depdiknas, (2007). Kecakapan Hidup Life Skill Melalui Pendekatan Pendidikan berbasis Luas. SIC: Jatim

Ulfa Triyani A. Latif. (2012). Kontribusi Konsep Diri, Motivasi Berprestasi 
Terhadap Hasil Belajar Biologi Siswa SMA di Makassar. Tesis. Universitas Negeri Makassar.

Wulandari B. (2013). Pengaruh Problem Based Learning Terhadap Hasil Belajar Ditinjau Dari Motivasi Belajar PLC Di SMK. Jurnal Pendidikan Vokasi, Vol 3 Nomor 2 Juni 2013.

Yamin. (2013). Paradigma Baru Pembelajaran. Jakarta : Referensi. 